\title{
I CALL MYSELF SNOB: POLITICS OF AESTHETICS OF KOREAN POETRY UNDER DICTATORSHIPS
}

\author{
Sunghee HONG, PhD student \\ Yonsei University \\ \#617 Oesol-gwan 50 Yonsei-ro Seodaemun-gu, \\ Seoul 03722, Republic of Korea \\ angela357@naver.com
}

\begin{abstract}
This study addresses the issue of politics of aesthetics in Korean poetry in regards of 'authenticity of snobbism' manifested in poems and essays published from late 1960s to 1980s under dictatorships. The special attention is on the double positioning of oneself as the accuser and the accused. The questions of the politics of aesthetics of Korean poetry, even the recent argument, has discriminated 'authenticity' from 'snobbism', in the needs to qualify literature as the accuser of the opportunism and passivism under the dictatorships. However, this dichotomy has restricted the political-aesthetic possibilities of literature to an exclusive property of poets or (poets as) 'citizens'. This study explores how Korean poetry generated the possibility of political aesthetics from every single snobbish corner of lives by placing 'the accuser' of the dictatorial government on the position of 'the accused' through its own voice. Poems and essays of Kim Soo-young, Kim Kwang-kyu and Lee Seong-bok will be significantly examined as what manifested the autoimmunity of literature beyond the pose of self-reflection.
\end{abstract}

Key words: authenticity, double-positioning, autoimmunity, Kim Soo-young, Kim Kwang-kyu, Lee Seong-bok, aesthetic politics 


\section{나는 자신을 속물이라 부른다: 독재 정권 하 한국시의 미학적 정치성}

논문초록: 이 글은 ‘속물의 진정성’이라는 주제로 한국 시의 미학적 정치 성을 다루는 글이다. 1960년대 후반에서 1980년대까지 독재 정권 하 출 간된 시와 산문을 다루면서, 이 글은 '비판하는 자'와 '비판 당하는 자'로 서 스스로를 동시에 위치시킴으로써 '겹쳐있는 존재'가 드러내는 가능 성을 논한다. 그간 한국 시의 정치성과 미학성과 관련하여 ‘진정성'은 언 제나 ‘속물성'과 명확히 차별되는 무엇으로 논의되어 왔다. 그 기저에는 독재 정권 하 기회주의자 혹은 ‘소시민'을 '비판하는 목소리'로서, 문학 이 더 나은 세계의 가능성을 배태하는 공간이 되어야 한다는 절박한 요 청이 자리하고 있었다. 그러나 이러한 ‘진정성' 기획은 정치적-미학적 가 능성을 소수의 문학인이나 그들이 상징하는 '시민'의 형상만이 전유할 수 있는 것으로 제한하였고, 그로써 문학의 정치성과 예술성은 고립된 방식으로만 논의될 수 있었다. 그러나 한국 시는 가장 ‘속물스러운, 일상 의 세목에서 그 속물성을 비난하는 자와 속물로서 비난 당하는 자의 목 소리가 겹쳐지는 방식으로 '진정성'의 이분법을 초과하는 정치적-미학 적 가능성을 형성해내고 있었다. 이 글은 김수영의 시와 산문, 김광규와 이성복의 시를 통해 한국 시가 ‘자기 반성'의 포즈를 넘어서는 ‘자기면 역'을 수행함으로써 독재 정권 하 문학의 정치성과 미학적 윤리성을 추 구해나간 방식을 독해해보고자 한다.

주제어: 진정성, 이율배반적 겹침, 자기면역, 김수영, 김광규, 이성복, 미학적 정치성

\section{NAZYWAM SIEBIE SNOBEM - POLITYKA ESTETYKI KOREAŃSKIEJ POEZJI W OKRESIE DYKTATURY}

Streszczenie: Niniejszy artykuł porusza kwestię polityki estetyki w koreańskiej poezji, w odniesieniu do „autentyczności snobizmu” zobrazowanej w wierszach oraz esejach autorstwa Kim Soo-young, Kim Kwang-kyu oraz Lee Seong-bok, opublikowanych w okresie dyktatury (od końca lat 60. aż po lata 80). Szczególną uwagę poświęcono zagadnieniu umieszczenia siebie w podwójnej roli - jako oskarżyciela i oskarżonego. Pytania dotyczące polityki estetyki w poezji koreańskiej, odróżniały „autentyczność” od „snobizmu”, co miało na celu zakwalifikowanie literatury jako oskarżyciela oportunizmu i pasywności w okresie dyktatury. Jednakże ta dychotomia ograniczyła polityczno-estetyczne możliwości wspomnianej literatury. Celem niniejszego artykułu jest zbadanie, w jaki sposób mogło dojść do powstania w poezji koreańskiej estetyki politycznej poprzez umieszczenie „oskarżyciela” dyktatorskiego rządu w pozycji „oskarżonego”. 
Słowa klucze: autentyczność, podwójna pozycja, autoimmunizacja, Kim Soo-young, Kim Kwang-kyu, Lee Seong-bok, polityka estetyczna

\section{Introduction}

This study, entitled "I Call Myself Snob: the politics of aesthetics of Korean poetry under dictatorships," addresses the issue of politics of aesthetics in Korean poetry in regards of 'authenticity of snobbism' manifested in poems and essays published from late 1960s to 1980s, as a key part of a bigger project I am working on. The questions of the politics of aesthetics of Korean poetry, even the recent argument, has discriminated 'authenticity' from 'snobbism', in the needs to qualify literature as the accuser of the oppressive violation and passivism under the dictatorships. However, Korean poetry has shown far beyond this binary structure. To show that, I would like to pay special attention to how poets, who closely focused on their ordinary everyday lives instead became "the accused" by themselves for indulging in opportunistic and obedient snobbism under the oppressive dictatorships. At the same time, I will show how 'the accused' became 'the accuser' through their own voice of criticism of themselves. Drawing on the works of Kim Soo-young, Kim Kwang-kyu, and Lee Seong-bok, I would illustrate how their self-positioning against-within snobbism developed into a poetic aesthetics and how their poetry was able to generate an 'authentic' politics through an autoimmune process.

\section{Needs for Literature as Authenticity of the Era}

To begin with, it will be helpful to look through how the idea of 'authenticity' has been constructed in Korean literary criticism field. It is well known that the 'authenticity' arose as critical value literature had to secure in 1980s among literary people, who encountered the brutal massacre of civilians by the military dictator on May 1980 questioning what the duty of literature is after such a tragedy. However, the ideal form of authenticity had already been manifested 
in the field of literary criticism since late 1960s through different notions to discover the people as 'the subjects' who actively survived the dictatorships: 'the people [minjung]', 'the national [minjok]', 'the citizen [simin]' and 'the individual [gaein]'.

Under the harsh condition of dictatorships, which encouraged people to be the passive or opportunist suit to the standard of the strong censorship, the critics urged themselves to question, what literature should be in the society. The question itself was a request for literature to be a realm of possibility which embraces the reality as it is but takes it far beyond from present condition. There was found the needs for 'authentic' reason for being of literature, severing itself from the 'inauthenticity' of the world. Only when literature embodies 'the authenticity', it could qualify itself as the critic of the world and the explorer of the new world. Configuration of the 'authentic subject', were called here to materialize this needs for authenticity of the literature. Baek Nakcheong, for example, claiming the realistic voice of oppressed people enables the political movement through solidarity, developed the notion 'the people' into the idea of 'the nation' and 'the citizen', the genuine people who would lead the progress of the world in right way. On the other hand, Kim Hyun found the imaginative power of 'the individual' significantly, which enables people to penetrate the truth of the world without overconfidence on any prerequisite value and seek for new possibility from the despair of given reality.

The notions the critics found as the figure of the subject differed according to which value they chose to concentrate, but the common denominator between the differences was that the figures were drawn as an ideal form of authenticity, such as 'authentic class', 'authentic community', 'authentic mind', and 'authentic inside'. The 'authenticity' allowed these idealized subjects to qualify themselves as 'the innocent' who takes off the charge of snobbism, which includes passivism and opportunism, and as 'the accuser' of the world. Presenting these figures of the subject, literature has found and confirmed its role as the genuine critics of the present and the active explorer for the new since then. A recent article, which has summarized and developed the arguments on the politics of poetry in 2000s, shows that the faith in the authenticity of literature against snobbism is still unshakable in literary field by asking a familiar question; "Here, who owns the authenticity?"

The reason this presupposition of the authenticity 
is problematic, even though it effectively helped critics to find the ontology of literature under the harsh condition, is because it offers literature the authority to idealize itself in its own necessity avoiding the self-accusation. If literature takes the position of critic of the world as what is 'authentic' and therefore 'qualified' without accusing its own idealization of authenticity, it would not be able to perform the role to precisely penetrate the structure of the world, as it would end up isolated from the society stuck in its own structure of self-satisfaction.

Researchers recently have criticized the limitation of the ideal figures of 'authentic' politics and aesthetics of literature claimed in criticisms since 1960s, focusing on how ineffectively the ideals could interact with the society. However, it is critical to see beyond the 'legitimacy' of the criticisms and penetrate the 'needs' for authenticity underlying them to read political and aesthetic power of Korean literature far beyond the binary structure of 'authenticity'. Therefore, this study aims to find the 'authenticity' as 'needs', which Charles Guignon called "the project of being authentic", and show politics of aesthetics in Korean poetry, which has already been beyond the 'project'. In next two chapters, I would like to examine poets, who has not been prepossessed with the needs for authenticity but still could generate political aesthetic possibilities of literature in their own way.

\section{Kim Soo-young: Becoming the 'Genuine' 'Snob'}

Kim Soo-young, who actively wrote poems and essays from the liberation in 1945 to his death in 1968, is one of the most beloved poet in Korea. Here is a famous quote among the public from his poem: "Why am I indignant over mere trifles". People like to quote this phrase sighing for their passiveness. However, Kim Soo-young's works in general show far beyond a pose of 'self-reflection'. While self-reflection somehow goes with self-justifying or self-soothing, Kim Soo-young does not leave a space for justification, for neither himself nor anyone else. He accuses everyone, including himself, as vividly manifested in his critical essay on snobbism. 
Asking me to write criticism of snobs is the same as asking Mr. So-and-so to set up a barbed-wire around the wall of the house that he himself has burgled, which is as awkward as it gets. (...) This kind of snobbism is, as I keep emphasizing, not just other people's problem but also mine. "The Sublime Snobs" (1967).

It is important to find that he is accusing himself with others through his own voice, which I'd like to call "double positioning of the accuser and the accused". This double positioning underlies much of Kim Soo-young's works, generating political-aesthetic possibilities beyond the 'authenticity' of the subject. For example, in a poem "James Deang", he describes his anger against a supervisor of a newspaper company who looks like 'James Deang', which might be James Dean. This guy visits the poet's house in a snowy morning to ascertain if the old boy that has delivered newspaper did not pocket the charge, before replacing the position with another boy. This situation itself and the man's minatory bossiness, which somehow reminds him of 'slave trade', provoke the poet. He describes this scene and his rage at the coercive air in the first half of this poem. However, the poem is continued with these lines:

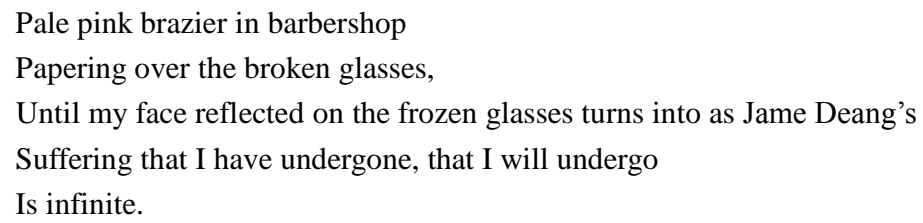

The reason his face is overlapped with James Deang's is not because he realized that he is not so different from the minatory and bossy guy. Rather, it is because he realized his own hostility. Like the red ink the barber marked on the misspelling on newspaper, he condemned the guy's job and attitude as "the wrong" and "the violence" qualifying himself as "the right" and "the innocent". He finds this dichotomous relationship of right and wrong as 'hostility', 'a light dream of winter', which let him attached to one and only 'right' thought, ultimately making him as a 'slave' of the structure of thought. So long as he stays in the position of 'the right', 'the innocent', therefore 'the accuser', he would end up in being outraged at the man, 'the accused' only, not 
being able to see the structure of the world which generates the system of 'slavery' as a whole between producer, messenger, and consumer. $\mathrm{He}$ would not find that he himself is a part of the system as a consumer, by naively calling himself as 'the innocent reader'. This unsuspicious hostility is what he found in the poem as "my arrogant dream", "my oversight".

Kim Soo-young refuses to see the world through 'right and wrong' binary structure not because he does not see the wrong as wrong, but because he believes he can be a performer of freedom when he is the one who realizes the strategy of the structure inside of it, which makes him feel 'innocent' and be "indignant over mere trifles" so that he can't see the structure itself. Only as the one, who is inside of the wrong of the structure but still can see the wrong as wrong, as 'the genuine snob who is self-destructible' as he mentioned in the criticism on snobbism, he himself, and his poetry itself could 'generate' the 'autoimmunity' of the society, the condition the structure cannot be completely dominant, and therefore the 'possibility' the world can be changed. In other words, by voluntarily positioning himself as the accuser and the accused at the same time, Kim Soo-young exercised his poetry to be a void of the world where the inevitability of revolution is ingenerated and, rather than to be the salvation by itself as studied before, to be a symptom, moment by moment, of salvation. This double positioning of 'the accusing accused' was the unique way of politicalaesthetic performance of Kim Soo-young's poetry, which even penetrated its own desire to be THE 'authentic' 'savior' of the world.

\section{Kim Kwang-kyu, Lee Seong-bok: Two Voices, Two Bodies}

While Kim Soo-young's double positioning in 1960s was performed based on active rage against the reality, Kim Kwang-kyu and Lee Seong-bok show different aspects of accusing-accused positioning. The dictatorship of 1960s ends in 1979 when the dictator was assassinated, but another military dictatorship era arrives in 1980, along with tragic repression of pro-democracy movement. Under the persistent despair, the self-destructing awareness of 'the genuine snob' turns into divided voices and bodies, which form different 
aspect of political-aesthetics in 1970s and 1980s.

Kim Kwang-kyu's first collection of poems published in 1979 shows the irreconcilable but also indivisible relationship between internalized voice of the accuser and lethargic language of the accused. In a poem "Dream and Sleep", for example, 'I' awakes from a paralyzing dream and finds himself in a coffin, dead. Hearing familiar voices mourning his death, he calls his crying family, but no one can hear him and his body is moved to crematorium. In the moment of burning, he catches the fire and flies to his house with the power of light. He calls the family again, but they still do not hear him and go inside the house closing the door leaving him behind. $\mathrm{He}$, crying desperately, falls asleep again.

There are two voices in this poem: the one of people present at the funeral and the speaker's. The speaker's voice accuses the people of not realizing what is really happening. But it remains inaudible. Meanwhile, the audible voice of 'the accused', which is 'real' for them, remains neglected by 'the accuser'. Then, what is really happening here? Which voice is 'real' and 'authentic'?

It would be easier to understand if we consider the accusing voice as what comes from outside of a self as in another poem of Kim Kwang-kyu.

\author{
Isn't it shameful \\ Isn't it shameful \\ Half listening the whisper of wind \\ We talked about health issue of middle age in vain \\ Moving one more step deeper into a swamp
}

"Shadow of Blurred Bygone Love" (1978-9)

The whisper of wind is a voice accusing 'us', who once used to be the subject of democratization movement on April 1960, of turning into "the generation afraid of revolution". 'We' almost hear the voice but cover it with a voice of snob, settling down in the given reality. Here, the accusing voice is not purely authentic as it remains merely as a 'shadow of blurred bygone love', and, at the same time, the voice of the accused is not merely inauthentic as it is the one that is real here. But importantly, both voices are actually the speakers own.

In this simultaneity of irreconcilability and indivisibility of voice, there is aporia poetry of the era had to deal with. For the question what poetry can do in this reality, Kim Kwang-kyu's 
poems did not decide one side between 'bygone revolution' and 'passive snobbism' but chose to carry out the question itself with two voices of a self. Doing so, he endured the suffering of his generation which is manifested in the last few lines of his collection: "It can't be started all over again / But it can't be over this way / Now I see that"

On the other hand, Lee Seong-bok, younger generation than Kim Kwang-kyu, shows different way of dealing with the aporia of the era. What the revolution in 1960 left to him was not an assertive 'voice' but a 'body' which spills pus or wither with no reason, a body of lethargic anesthesia. Since then, the weeping and itching body kept lying down, falling asleep, fossilizing, playing dead, or drowning, still staying safe and unharmed.

I jump if feeling too dizzy that is so, safe

Yet I have never injured no matter ears eyes mouth and nose are decaying

Everything is lie

“About Memories" (1978-9)

Meanwhile, there is another body. This body hurts, swells up, or passes away over and over again while being cut down, nailed, or abused. It is a woman's body, mostly mother's or sister's. Remarkably, these two bodies fit with reversed states of mind.

Into the music my sister listens to a guy was

coming slowly I hated that My music

is dark and gloomy more than death and there to keep my feet

from escape weeds grows, that guy

who is he would it be okay if she has beautiful loving relationship

wondering it I fell asleep

“At Beloved Prostitute Quarters” (1978-1979)

The inside of 'I' is dark and gloomy because he thinks "everyone is taken ill but no one is sick". And because he thinks so, he wonders if his sister's happiness is acceptable. However, paradoxically, his own body is not sick, staying unharmed, while his sister's body experiences ceaseless violence. Here, which one between his own illness in mind and the sister's physical suffering is genuine? Which one is the 'authentic' agony? Even though Lee Seong-bok's poems are 
mostly full of the narration of 'I' with sick mind and weeping body, but he always reminds himself of the suffering bodies of mother and sister.

\author{
Mom, one day pushing out clouds of evening sweety \\ this is Jerusalem my room with wall made of wail \\ Jordan, calm Jordan, cross now, hurry if you say
}

Would I cross? Which one is ferryboat? No

that is my sister fallen mom, she is sick

"Love Diary" (1978-9)

The suffering body of woman lets him find his own body weeping and drowning, see his own great suffer of mind, but also acknowledge his falling but still unharmed body, and therefore, it lets him finally imagine the agony of the woman's body and her mind which he always will see with love. Not satisfying himself with his own suffer in mind but keeping loving the suffering body of others which remains un-imaginable, 'I' holds himself between two bodies and two minds of this era. This is how Lee Seong-bok's poetry goes beyond its own question of authenticity and generates the possibility of politics and aesthetics of 'sickness.' Two voices in Kim Kwangkyu's poetry and two bodies in Lee Seong-bok's were two different aspects of questioning how a subject would shoulder the undeniably internalized double positioning of the accusing-accused, and answering that own question with practice of indivisibly divided or divisively entangled selves that would thirst for 'authenticity' but never allow themselves fulfill it.

\title{
Conclusion
}

This study briefly showed how Korean poetry has attempted to overcome the needs for authenticity to find its own position in harsh political and aesthetic condition under dictatorships. I've mentioned that what Charles Guignon called "the project of being authentic" restricts literature to self-assurance as a qualified, trustworthy critic of the world, which would limit possibility of literature itself. I believe 
the poetry of the three poets I have drawn effectively shows how Korean literature has encouraged itself to find new political and aesthetic possibilities from enduring the double-positioned state with no one true authenticity.

In the project I would like to work on, the questions of how 'snobbism', beside 'authenticity', has worked in Korean literary field, and how 'politics' and 'aesthetics' of Korean literature have developed as indivisibly divided idea while being considered to be irreconcilable by critics and poets would be closely examined. The final goal of my project will be to show how Korean contemporary literature has developed the ethics of 'truth' as 'ugly truth' with political aesthetics or aesthetic politics of the double positioning of the accused and the accuser with snobbish authenticity and authentic snobbism.

\section{Bibliography}

Cho, Kang-sok. 2008. A Study on Kim Soo-young's and Kim Choonsoo's Poetics as Dissonant Aesthetic Appearance. Dissertation, Yonsei Universisty.

Cho, Yeon-jung. 2016. "The (Im)Possibility of the Literature of the Periphery or the Limitations of the Popularization of Literature-Revisiting Paik Nak-chung's "Citizen/ National/ People's Literature Theory"'. In Humanities Research: 51.

Choi, Wonsik et al. 1988. "Discussion: National Literature and People Literature". Creation \& Criticism: $16: 1$.

Guignon, Charles. 2004. On Being Authentic. Routeledge.

Jeong, Hanah. 2012. "Ethics of Movements and the Moral of Campaigns - a pragmatic supplement to the "politics and poetry' argument". The Journal of Korean Modern Literature: 35.

Kim, Hyun. 1992. Analysis and Interpretation; Visible Abyss and Invisible Historical Perspectives. Moonji Publishing Co.

Kim, Hyun. 1992. Imaginary World of Young Poets; Scene of Words. Moonji Publishing Co.

Kim, Kwang-kyu. 1979. Last Dream Bedews Us. Moonji Publishing Co.

Kim, Soo-young. 2003. Complete Works of Kim Soo-young 1 Poetry. 
Sunghee HONG: I Call Myself Snob: Politics of Aesthetics of Korean...

Minumsa.

Kim, Soo-young. 2003. Complete Works of Kim Soo-young 2 Essay. Minumsa.

Lee, Seong-bok. 1980. When Will the Rolling Stone Awaken. Moonji Publishing Co. 